\title{
LJOURNAL.RU
}

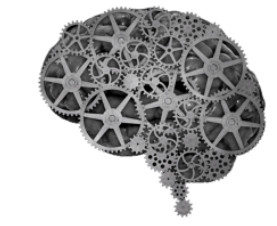

COMPANY GROUP "INTELLEKT"

\author{
Упоров И.В. \\ Краснодарский университет МВД России \\ Краснодар, Россия
}

doi: 10.18411/1j2016-3-40

\section{Студенты разного уровня подготовки: как учитывать данное об- стоятельство в процессе обучения?}

\begin{abstract}
doi:10.18411//j2016-3-40
Аннотация: В статье обосновываются апробированные автором инновационные методы проведения семинарских занятий в процессе обучения студентов по правовым дисциплинам в высших учебных заведениях. Предлагается, в частности, создавать из числа студентов творческие группы по отдельным вопросам, которые готовят коллективный доклад. Кроме того, наиболее подготовленным студентам рекомендуется выступать в роли консультантов для менее подготовленных студентов.

Ключевые слова: инновационные методы обучения, студенты, семинарские занятия, разный уровень подготовки, творческие группы, студенты-консультанты.
\end{abstract}

Abstract: In this article the author tested innovative methods of classes in the course of training stu-dents on the legal disciplines in higher education. It is proposed, in particular, to create a number of creative groups of students on certain issues, which prepare a collective report. In addition, the best prepared students are encouraged to act as consultants for the less-prepared students.

Keywords: innovative teaching methods, students, seminars, different levels of training, creative groups, consultants and students. 
В каждом высшем учебном заведении сталкиваются с проблемой, вытекающей из разного уровня подготовки студентов, волею судьбы оказавшихся в данном вузе. Эта проблема проявляется на первых же семинарских и практических занятиях. Перед преподавателем возникает сложный вопрос - на какой уровень студентов ориентироваться при проведении семинарских и практических занятий: менее подготовленных, среднего уровня подготовки, более подготовленных. Выбор делается обычно, исходя из большинства одной из трех отмеченных групп. При этом любой вариант имеет недостатки, в частности, при выборе первого варианта у лучших студентов вынужденно происходит торможение их развития, при выборе третьего варианта менее подготовленные отстают безнадежно, при выборе второго варианта - менее подготовленные продолжат отставать, но не безнадежно, а более подготовленные - тормозиться, но в меньшей степени.

Еще одна проблема заключается в том, что во многих вузах, во всяком случае, в государственных университетах, количество студентов в группах довольно большое (до тридцати человек), что объективно не позволяет каждому студенту на семинарских занятиях обрести необходимую практику подготовки вопросов и выступлений с сообщениями (докладами), окунуться в атмосферу дискуссий, выработки навыков отстаивания и аргументации своей позиции и т.д. Учитывая экономический кризис в стране, рассчитывать на то, что вузы пойдут на расширение штата преподавателей и соответственно учебные студенческие группы будут уменьшены вдвое (это был бы, очевидно, оптимальный вариант) не приходится.

Опыт педагогической деятельности автора, связанной с проведением лекционных и семинарских занятий по правовым дисциплинам (в частности, по муниципальному праву, конституционному праву, финансовому праву) позволил выработать некоторые методы обучения, позволяющие в определенной степени нивелировать указные проблемы. 
Первый из таких методов заключается в создании из числа студентов творческих групп для подготовки сообщения (доклада) по конкретному вопросу (как правило, из числа наиболее значимых) семинарского занятия. Этот вопрос предлагается разделить на несколько взаимосвязанных составляющих, каждую из которых должен взять член творческой группы. Во время коллективного ответа предполагается выслушивание не просто ответов по отдельным составляющим, но и обобщение по всему вопросу.

Очень важно здесь то, что разбивку заданного студентам вопроса (или выбранного самими студентами из перечня предлагаемых, что автор считает предпочтительным) на отдельные составляющие, распределение этих составляющих между членами творческой группы, способы поиска информации, ее обобщения и другие особенности коллективного ответа определяются самими студентами - членами творческой группы.

Состав творческих групп в большинстве случаев также определяется самими студентами. Однако в отношении менее активных студентов автор применял метод «принуждения» и включал их в состав творческих групп по определенным вопросам, в некоторых случаях их приходилось «прицеплять» к уже устоявшимся творческим группам. По количеству творческие группы составляют от двух до четырех студентов, при этом формировались и постоянные творческие группы. Но в любом случае в составе группы должен был быть хотя один более подготовленный студент.

Как показывает опыт, использование творческих групп стимулирует студентов занимать более активную позицию, поскольку им нужно собираться во внеучебное время и обсуждать план подготовки к семинарскому занятию по конкретному вопросу. Повышается и ответственность каждого члена группы ведь если он не подготовит свою часть коллективного ответа, то подведет своих товарищей. Для более подготовленных студентов участие в таких творческих группах также имеется стимул, поскольку им приходится делать обобщение по заданному вопросу от имени творческой группы, включая обзор 
использованной литературы, что является для студентов довольно сложным делом.

Что касается оценок, которые нужно проставлять студентам, что автор занимает здесь следующую позицию. Во-первых, мы полагаем, что существующие оценки ответов студентов (неудовлетворительно, удовлетворительно, хорошо, отлично) являются анахронизмом, и от них следует отказываться, заменяя стимулы лучшим студентам в иных формах и оставив формальный минимум (освоил или не освоил данную тему, данную учебную дисциплину, данную учебную программу и т.д.). Во-вторых, поскольку оценки пока еще являются обязательными, то автор их, разумеется, ставит. Как правило, иссправшивается мнение самой творческой группы - каким образом ставить оценки: каждому студенту творческой группы в отдельности или одну и ту же оценку всем студентам данной группы вне зависимости от вклада каждого в коллективный ответ. В подавляющем большинстве срабатывает принцип коллективной ответственности. Однако преподаватель оставляет за собой право для отдельных студентов в зависимости от разных обстоятельств выставлять еще и индивидуальные оценки.

Соотношение коллективных (в составе творческих групп) и индивидуальных ответов на семинарских занятиях в каждой учебной группе различно и во многом зависит от активности самих студентов, в среднем же соотношение составляет «пятьдесят на пятьдесят».

Помимо этого, автор использует также привлечение более подготовленных студентов в качестве консультантов для менее подготовленных студентов. Обычно это имеет место, когда отстающему студенту поручается подготовить вопросу к семинарскому занятию в индивидуальном порядке. Здесь расчет на то, что студент-консультант фактически также готовится по тому же вопросу и помогает своему товарищу, при этом он испытывает определенную ответственность за своего подопечного. В практике автора был случай, когда студентка-консультант напутствовала своего подопечного словами: «Не подвели 
меня, пожалуйста!», не без волнения слушала его ответ и была очень довольна положительным результатом.

Конечно, эти методы не бесспорны, но они, на наш взгляд, позволяют в один и тот же временной отрезок семинарского занятия в большей степени активизировать учебный процесс усвоения знаний студентами. 